\title{
RELAȚIE ȘI DIALOG ÎNTRE BISERICA ORTODOXĂ ROMÂNĂ ŞI BISERICA ORTODOXĂ DE RIT VECHI DIN ROMÂNIA
}

Andrei MOTORA*

\begin{abstract}
Relationship and Dialogue between the Romanian Orthodox Church and the Lipovan Orthodox Old-Rite Church in Romania ${ }^{1}$. The relationship between the Romanian Orthodox Church and the other Romanian cults is based on dialogue and the collaboration on different social projects. With respect to the connection between our Church and the Old Rite Orthodox Church we might say that it began to exist since the XVIIIth century, when the first communities of old believers settled in our country. In this study, we want to offer a radiography of the relationship and dialogue mentioned above, starting with the first and only book about Lipovans found in the Romanian Theology, written by Archbishop Melchisedec Stefanescu, and continuing with the establishment of the old style theology class, and ending with its involvement in keeping religion in the school curricula. Our research is meant to reveal that the two Churches have always had a positive dialogue which hopefully may become more productive in the future.
\end{abstract}

Keywords: dialogue, relationship, starovers, old-believers, Romanian Orthodox Church, Old Rite Orthodox Church in Romania.

\section{Introducere}

După ce comunitatea staroverilor este condamnată religios și politic prin hotărârile soboarelor bisericești ținute la Moscova între anii

* PhD Student, Faculty of Orthodox Theology at "1 Decembrie 1918" University, Alba Iulia, Romania.

${ }^{1}$ Studiu redactat sub îndrumarea Pr. Prof. Univ. Dr. Habil. Mihai Himcinschi, care și-a exprimat acordul pentru publicare. 
1666-1667, începe o perioadă lungă de persecuții sistematice ce i-a făcut pe membrii ei să se stabilească în afara granițelor imperiului rus. Țările Române aveau să fie un loc de refugiu pentru mulţi dintre ei, deoarece situația politică și religioasă din ele a permis acest lucru. Astfel, la mijlocul secolului al XVIII-lea apar primele comunităţi de staroveri pe teritoriul țării noastre, urmând ca orașul Brăila să devină sediul Mitropoliei Ortodoxe de Rit Vechi de la Fântâna Albă, după ce Bucovina este desprinsă de România la 29 iunie 1940.

Cercetarea de față pleacă de la următoarea întrebare: Putem vorbi de bună-relaţionare și de un dialog productiv între Biserica Ortodoxă Română și Biserica Ortodoxă de Rit Vechi din România? Vom pleca de la prima și singura carte elaborată despre lipoveni din teologia românească, aparținând episcopului ortodox Melchisedec Ștefănescu, care prezintă într-o manieră deloc favorabilă cultul vechilor-credincioși ruși, urmând ca spre final să descriem cele mai recente momente de dialog și relație dintre cele două culte.

Am ales să tratăm acest subiect, fiind convinși că misiunea de astăzi a Bisericii trebuie să fie centrată pe dialog, pe relație și conlucrarea în diferite prilejuri și situații oferite de peisajul pestriț al societăţii, înainte de a parcurge alți pași spre comuniune sau conslujire ${ }^{2}$.

În ceea ce privește stadiul cercetării, despre acest subiect s-a scris foarte puțin. Am găsit referințe sporadice despre acest subiect în cărți și periodice lipoveneşti și cu mult mai puține în cele aparținând Bisericii noastre. Noi însă am reuşit, pe cât posibil, să folosim în acest studiu toate aceste mențiuni privind dialogul şi relaționarea dintre cele două culte, putând emite la final o concluzie pertinentă și obiectivă.

\section{Episcopul Melchisedec Ștefănescu și credincioșii de rit vechi}

În a doua jumătate a secolului al XIX-lea vede lumina tiparului o carte sau, putem spune, o monografie despre lipoveni, singura scrisă în teologia românească până astăzi, aparținând eruditului episcop ortodox român Melchisedec Ștefănescu (1823-1892), lucrare ce a văzut lumina tiparului în anul 1871. Titlul acesteia este Lipovenismul, adică

2 Vezi: Mihai Himcinschi, Misiune și dialog - ontologia misionară a Bisericii din perspectiva dialogului interreligios, Alba Iulia, Edit. Reîntregirea, 2003. 
schismaticii sau rascolnicii și ereticii rusești ${ }^{3}$. Această lucrare este o monografie istorică, bazată pe informații directe și precise, extrase de la fața locului, pentru că cele mai mari comunități de staroveri le găsim în Moldova și în nordul Dobrogei. Trebuie spus încă de la bun început că subiectul nu este tratat deloc într-o manieră pozitivă, iar acest lucru se vede încă din titlu, prin folosirea celor trei apelative cu tentă negativistă şi acuzatorie: schismatici, rascolnici și eretici. Autorul cărții evidențiază câteva aspecte privind relația credincioșilor ruși de rit vechi cu Statul Român și cu Biserica Ortodoxă Română: nu respectau prevederile legale, erau împotriva școlarizării, a armatei sau a introducerii actelor de stare civilă, refuzau pomenirea domnitorului la Sfânta Liturghie, organizau manifestații publice prin care cereau protecția sultanului ${ }^{4}$.

„Această operă științifică a rămas până astăzi cel mai vechi izvor de informație şi normă asupra tuturor acestor schisme rusești din epocă, a

${ }^{3}$ Titlul original este Lipovenismulu adică schismaticii séu rescolnicii și ereticii rusesci și avea să fie una dintre cele mai voluminoase cărți scrise de episcopul român. Se pare că subiectul era incitant și interesant pentru societatea de atunci, tocmai pentru că lucrarea avea să fie tradusă în limba greacă și tipărită la Constantinopol în anul 1876. Mircea PĂCURARIU, Dicționarul teologilor români, ed. a II-a, București, Edit. Enciclopedică, 2002, p. 483-485.

${ }^{4}$ Alexandru IONIȚĂ, Episcopul Melchisedec Ștefănescu al Romanului. Viața şi activitatea (1822-1892). Teză de doctorat, Constanța, 1999, p. 257. Trebuie precizat un lucru important. Din cercetarea personală a subiectului nu am găsit prea multe surse în care să se descrie modul de activitate intolerant și tensionat al comunității ortodoxe ruse de rit vechi pe teritoriul țării noastre. Trebuie să știm faptul că în perioada în care episcopul Melchisedec redacta această lucrare exista o tensiune generală privind situația religioasă din Țările Române. Societatea intra încet în modernitate, Biserica începe să fie pusă în banca ei pentru a fi dominată de politic etc. Toate acestea aveau să aducă mutații marcante asupra tuturor comunităților religioase, mai ales asupra celor de mici dimensiuni. Aceste manifestații ale staroverilor, descrise de episcopul Melchisedec, mai pot fi analizate și din altă perspectivă. Credincioșii de rit vechi purtau în spate o tradiție de mai bine de două secole de persecuții venite din partea conaționalilor lor, fapt ce i-a făcut să se împrăștie în întreaga lume. O situație dureroasă, spunem noi. Astfel, cele precizate în carte de episcopul român pot fi considerate ca fiind doar niște reflexe involuntare de conservare a credințelor lor religioase și de apărare a cultului în fața a ceea ce ei vedeau ca fiind o amenințare. Mai mult decât atât, vom vedea pe parcursul studiului că această comunitate religioasă avea să aibă o deschidere sinceră demnă de apreciat pentru dialogul dintre culte în secolele XX și XXI. 
căror învăţătură și practici au fost calificate de Melchisedec «fanatice, superstițioase și antiumane» - p. 31-35. (...) Ceea ce deosebește această operă de celelalte scrieri ale episcopului Melchisedec este stilul cursiv și fără digresiuni lăturalnice. Până în prezent nu s-a scris la noi o a doua lucrare pe această temă și de aceeași valoare" ${ }^{25}$.

Chiar dacă lucrurile au fost spuse de episcopul român în lucrarea sa într-o manieră mai acidă, informaţiile despre lipoveni adunate într-un volum au fost inedite și bine receptate de societate, chiar și de către comunitățile lipovenești. Iată ce ne spune în acest sens istoricul moldovean Petru Flenchea, în lucrarea Municipiul Roman și comunitatea ruşilor lipoveni:

„«Lipovenismulu adică schismaticii sau rascolnicii şi ereticii rusesci», a fost cea mai completă lucrare publicată în limba română, în secolul al XIX-lea despre ruşii-lipoveni, idee subliniată nu numai de membrii Academiei Române, a cărui membru a fost, dar şi mai târziu chiar de către membrii comunităţii ruşilor-lipoveni din secolul al XX-lea. Informaţiile pe care le-a oferit episcopul Melchisedec Ştefănescu au fost atât de valoroase încât toţi acei reprezentanţi ai comunităţii ruşilor-lipoveni care au scris despre grupul lor, le-au preluat şi utilizat, ele fiind cele mai complete pentru acea perioadă şi nu numai"6.

În anul 2007, avea să apară un studiu analitic şi cu caracter de contraargument, intitulat Melchisedec și lipovenii ${ }^{7}$, care prezenta perspectiva lipovenească asupra cărții scrise de Episcopul Melchisedec Ştefănescu, aparținând reputatului lingvist român Victor Vascenco. Studiul este savuros și în cadrul său sunt surprinse, într-un mod elevat și academic, toate detaliile unui contraargument privind ideile prezentate de ierarhul român în cartea sa. Victor Vascenco ține să evidențieze, printre altele, că vorbim de o intoleranță religioasă iar episcopul Melchisedec pune în aceeași oală pe toți credincioșii de rit vechi sub numele de

${ }^{5}$ Ibidem, p. 258.

${ }^{6}$ Petru FlencheA, Municipiul Roman şi comunitatea ruşilor-lipoveni, București, Edit. Papirus Media, 2009, p. 76.

7 Încă de la început trebuie să spunem că autorul, pe tot parcursul studiului, folosește doar numele de Melchisedec, făă a-i prezenta titulatura eclezială și nici numele de familie, ceea ce considerăm a fi o lipsă de respect față de eruditul cleric ortodox român. 
lipoveni, ceea ce este greșit ${ }^{8} . \mathrm{Cu}$ toate acestea, spre final, Victor Vascenco, menționează faptul că opera lui Melchisedec ar fi arătat cu totul altfel, după aproape un secol și jumătate, adică astăzi, când lipovenii sunt o comunitate de sine stătătoare și angajată deschis în dialogul cu Biserica Ortodoxă Română și cu Statul Român:

„Dacă Melchisedec și-ar fi scris cartea în zilele noastre, când staroverii din sud-estul Europei reprezintă, prin Comunitatea Ruşilor Lipoveni din România (înființată în 1990), o minoritate înfloritoare, o etnie stabilă, istoriceşte constituită pe baza unei unităţ̧i lingvistice şi teritorial-insulare, lucrarea sa ar fi avut o orientare diferită"s.

$\mathrm{Cu}$ toate acestea, autorul acestui studiu interesant și bine argumentat, consideră cartea episcopului Melchisedec Ștefănescu ca fiind o lucrare de referință pentru perioada în care a fost scrisă:

„Lăsând la o parte aspectele strict ecleziastice, cu deosebire cele liturgice, domeniu în care ne declinăm competența, cartea lui Melchisedec constituie, sub raportul contribuțiilor istorice și demografice, o lucrare de pionerat, implicit o pagină de referință privind perioada austro-moldavo-otomană a diasporei ruşilor lipoveni din România"10.

\section{Rușii lipoveni și conferințele de pace}

Războaiele mondiale aveau să zdruncine din temelii întreaga lume și să îi facă pe oameni să își dorească cu ardoare pacea și liniștea dintre popoare. Se conturează, putem spune, chiar un sentiment de reticență față de conflicte și o dorință asiduă pentru dobândirea și menținerea păcii în toate segmentele societății. Biserica a fost și ea impulsionată de această tendință de promovare a păcii specifică celei

8 Remarca este adevărată și obiectivă, pentru că este greșit a stigmatiza întreaga comunitate staroveră pentru greșelile și tensiunile provocate de alți credincioṣi de rit vechi mult mai fanatici, extremiști și care nu au acceptat principiile și ierarhia Mitropoliei de la Fântâna Albă.

${ }^{9}$ Victor VASCENCO, „Melchisedec și lipovenii”, în Zorile, 5 (176)/2007, p. 11.

10 IDEM, „Melchisedec și lipovenii”, în Romanoslavica, vol. XLII, București, Edit. Universității din București, 2007, p. 139. 
de-a doua jumătăți a secolului XX. În acest context şi sub influența acestei tendințe pacifiste, putem spune că a avut loc și împăcarea (cel puțin formală) dintre Biserica Ortodoxă și Biserica Romano-Catolică, care s-a încununat cu ridicarea, la data de 7 decembrie 1965, a anatemelor rostite la 14 și 24 iulie 1054.

Modificări în sens pozitiv aveau să se înregistreze și în relația dintre Biserica Ortodoxă Rusă și susținătorii ritului vechi. Ca argument avem condoleanţele pe care Locţiitorul de Patriarh al Bisericii Ortodoxe Ruse, Mitropolitul Pimen al Crutiţelor şi Kolomnei, le adresează celor trei episcopi de rit vechi (Nicodim, Irinarh şi Ioasaf), cu prilejul trecerii la cele veşnice a întâistătătorul Bisericii creştine de rit vechi din Uniunea Sovietică, Iosif, la data de 3 noiembrie 1970. Prezentăm aici și conținutul telegramei de mulțumire pentru condoleanțele primite, venită din partea ierarhilor de rit vechi, tocmai pentru că ea reprezintă dovada vie a faptului că situația dintre cele două culte s-a îmbunătăţit simţitor:

„Arhiepiscopia de rit vechi a Moscovei şi a întregii Rusii transmite IPS (Înaltpreasfinţiilor - n.n.) Voastre şi Sfântului Sinod al Bisericii Ortodoxe Ruse recunoștința ei pentru condoleanțele transmise în legătură cu încetarea din viață a Arhiepiscopului de rit vechi Iosif al Moscovei şi al întregii Rusii. Cu dragoste frățească, Episcopul de rit vechi Nicodim al Chişinăului, locţiitor de Arhiepiscop al Moscovei şi al întregii Rusii"11.

Un an mai târziu vine şi o oarecare recunoaştere a cultului ortodox de rit vechi din Rusia prin ridicarea anatemelor aruncate în anii 1656 şi 1667 asupra ortodocşilor ruşi de rit vechi. Hotărârea a fost luată de către Sfântul Sinod al Bisericii Ortodoxe Ruse în data de 2 iunie $1971^{12}$. In luna noiembrie a aceluiași an, Mitropolitul Nicodim al Leningradului şi Novgorodului, în calitate de preşedinte al Serviciului Patriarhiei din Moscova pentru relaţii bisericeşti externe, a adresat conducătorilor şi comunităţilor ortodoxe ruse de rit vechi din Uniunea Sovietică o comunicare scrisă prin care vorbea despre ridicarea

${ }^{11}$ REDACȚIA, ,Moartea Arhiepiscopului Iosif, întâistătătorul Bisericii creştine de rit vechi din Uniunea Sovietică”, în Biserica Ortodoxă Română, 3-4/1971, p. 279.

12 IDEM, „Ridicarea anatemei aruncate de sinoadele Bisericii Ortodoxe Ruse de la 1656 şi 1667 asupra «riturilor vechi» şi asupra credincioşilor de rit vechi”, în Biserica Ortodoxă Română, 9-10/1971, p. 1004-1005. 
anatemelor şi despre încercarea de a se stabili o relaţie amiabilă între cele două culte ortodoxe ${ }^{13}$.

Pe plan intern, Biserica Ortodoxă Română, în calitate de cult dominant, a inițiat o serie de conferințe și de consfătuiri prin care se promova pacea. Este de menționat faptul că reprezentanții Bisericii Ortodoxe de Rit Vechi din România au dat curs și au onorat în permanență invitaţiile de participare. Acest lucru arată clar deschiderea ierarhiei ortodocşilor de rit vechi spre dialog și spre buna-relaţionare dintre culte. $\mathrm{Ca}$ argument avem participarea conducătorilor religioși de rit vechi din România, în frunte cu Mitropolitul Tihon Cacealchin (1942-1968), la Consfătuirea din 23 iunie 1949 dintre cultele creștine din România, organizată la Palatul Patriarhal din București sub conducerea Preafericitului Justinian Marina, Patriarhul Bisericii Ortodoxe Române. Din declarația Patriarhului se poate vedea armonioasa relație și fructuosul dialog dintre Biserica noastră și Biserica Lipovenească:

„Pot mărturisi, de asemenea, în calitatea mea de preşedinte al şedinţelor ţinute de conducătorii Cultelor religioase din ţara noastră, că şi Cultul creştin de rit-vechi, prin participarea activă a reprezentanţilor săi la toate consfătuirile şi acţiunile amintite a dat o contribuţie preţioasă la crearea acelei poziţii legale de egalitate, de respect reciproc şi de colaborare armonioasă între Cultele religioase din ţara noastră şi a ajutat la stabilirea unui spirit evanghelic de dragoste şi pace între credincioşii Cultelor din ţara noastră" ${ }^{14}$.

Consfătuirea pentru pace menționată mai sus a dat tonul organizării unor alte astfel de întâlniri, cu același scop, și pe plan local. Ne-am aplecat atenția asupra conferințelor intercultice din zona Moldovei, unde se află cele mai mari comunități de ortodocși de rit vechi din țara noastră și am avut plăcerea de a remarca că reprezentați ai cultului lipovenesc au fost prezenți și chiar s-au înscris la cuvânt. Spre exemplu, preotul lipovean Istrate Ivanov, la Conferința de Pace de la Piatra Neamț din 30 septembrie

13 IDEM, „Comunicarea adresată conducătorilor şi comunităţilor Ortodoxe Ruse de rit vechi de către serviciul Patriarhiei din Moscova pentru relaţii bisericeşti externe", în Biserica Ortodoxă Română, 3-4/1972, p. 320.

14 Ștefan AlEXE, „Relațiile Bisericii Ortodoxe Române cu celelalte culte religioase din țara noastră”, în Ortodoxia, 2/1973, p. 201. 
1954, menționa faptul că toți clericii de rit vechi promovează pacea în predici și organizează în parohii, de două ori pe an (primăvara și toamna), consfătuiri care promovează ideea de pace ${ }^{15}$. Axându-ne pe subiectul analizat în cercetarea noastră, putem spune că Biserica Lipovenească a arătat o largă deschidere față de orice inițiativă a Bisericii Ortodoxe Române, încercând să fundamenteze o bună relaționare și un dialog productiv.

\section{Patriarhul Justinian Marina și Mitropolitul Ioasaf Timofei}

La data de 29 noiembrie 1968, Preafericitul Justinian, Patriarhul Bisericii Ortodoxe Române, a participat, alături de câțiva membri ai Sfântului Sinod și clerici care făceau parte din administrația patriarhală, la instalarea Ierarhului Ioasaf Timofei în scaunul de Mitropolit al cultului creștin de rit vechi. Acest gest este, putem spune, unul dintre primele contacte directe dintre cele două Biserici, fiind o dovadă vie a relației și dialogului dintre ele. În cadrul mesei festive organizate de Departamentul Cultelor de pe lângă Consiliul de Miniștri, Întâistătătorul Bisericii noastre a rostit o solemnă și profundă cuvântare din care vom oferi doar un fragment care ni se pare mai sugestiv:

„În ce privește Cultul creștin de rit vechi, sunt bucuros să dau mărturie, cu acest prilej, că încă de acum aproape 20 de ani, conducătorii (...) au participat la toate consfătuirile avute de reprezentanții cultelor religioase din țara noastră, cu ocazia unor evenimente importante din viața poporului român, și-au dat adeziunea la toate intervențiile și acțiunile întreprinse de aceștia, semnând apelurile și mesajele adresate fie credincioșilor cultelor din țara noastră, fie conducătorilor bisericești din lume, în legătură cu pacea și înfrățirea între oameni și popoare...

15 Constantin STĂCESCU, „Conferința interconfesională pentru Pace de la Piatra Neamț”, în Mitropolia Moldovei și Sucevei, 11/1954, p. 90-92. Redăm şi alte consemnări din revistele teologice care să argumenteze cele prezentate aici:

REDACȚIA, „Acțiuni pentru întărirea păcii. Conferințe interconfesionale”, în Mitropolia Moldovei și Sucevei, 5/1956, p. 301-306.

Tiberiu MeleșCanu, „Conferințe intercultice”, în Mitropolia Moldovei și Sucevei, 8-9/1956, p. 503-507.

REDACȚIA, „Manifestările clerului în lupta pentru pace împotriva experiențelor termonucleare", în Mitropolia Moldovei și Sucevei, 8-9/1957, p. 710-713. 
Cultul creștin de rit vechi, prin participarea activă a reprezentanţilor săi la toate consfătuirile și acțiunile amintite, a dat o contribuție prețioasă la crearea acelei poziții legale de egalitate, de respect reciproc și de colaborare armonioasă între cultele religioase din Republica noastră, a ajutat la stabilirea unui spirit evanghelic de dragoste și pace între credincioșii Cultelor din țara noastră, a contribuit la zidirea unităţii spirituale a tuturor fiilor patriei noastre" 16 .

Acest eveniment, după cum putem observa, este o dovadă vie a dialogului și a bunei relaţionări dintre cele două culte, aspect ce se va accentua tot mai mult în deceniile ce au urmat.

\section{Clasa de teologie pentru Biserica Ortodoxă de Rit Vechi}

După ce democrația se instaurează și în țara noastră, cultele au o libertate de manifestare mult mai mare, iar relaţia dintre cele două culte pe care le avem în discuţie s-a fundamentat și mai mult. Biserica Lipovenească se confrunta cu o problemă, și anume lipsa unei forme de învățământ instituționalizate în vederea pregătirii tinerilor băieți pentru funcția clericală. Primul pas în reglementarea acestui aspect avea să fie făcut de către ierarhia cultului de rit vechi, care cere o întâlnire de lucru cu conducerea Bisericii Ortodoxe Române. Astfel, la data de 4 aprilie 2002, delegația cultului de rit vechi, condusă de Înaltpreasfințitul Leontie, Arhiepiscop de Fântâna Albă și al tuturor creștinilor de rit vechi din întreaga lume, este invitată de către Preafericitul Teoctist, Patriarhul Bisericii Ortodoxe Române, la o întrevedere la Reședința Patriarhală.

Pe lângă prezentările de ordin istoric privind cultul de rit vechi, delegaţia vechilor credincioşi a cerut patriarhului acceptul de a se forma o clasă de învățământ teologic destinată tinerilor lipoveni în cadrul Seminarului Teologic Ortodox „Sfântul Vasile cel Mare” din Iași. De ce se dorea acest lucru? Pentru că până atunci, pregătirea tinerilor pentru statutul de cleric era făcută mult mai rudimentar și într-o manieră deloc instituţionalizată. Adică, erau organizate școli de vară la nivelul mănăstirilor

${ }^{16}$ Întregul discurs, precum și alte detalii despre eveniment, pot fi consultate la următoarea sursă bibliografică: REDACȚIA, „Participarea Prea Fericitului Justinian la instalarea noului Mitropolit Ioasaf Timofei”, în Biserica Ortodoxă Română, 11-12/1968, p. 1269-1271. 
și al parohiilor sau teologia se prelua ,prin tradiția cunoștințelor bătrânilor creștini educați care și ei, la rândul lor, au preluat, în aceeași formă, învătătura de la înaintași”"17. Programa școlară avea să fie aceeași cu cea studiată de către seminariștii ortodocși români, la care se va adăuga cursuri de limba slavonă și de aspecte tipiconale și liturgice specifice.

Inițiativa a fost salutată de către patriarhul Bisericii noastre, care a precizat că va face tot ceea ce este posibil pentru înfăptuirea acestui demers. Astfel,

„începând cu 15 septembrie a.c. ${ }^{18}$, în cadrul Seminarului Teologic Ortodox «Sf. Vasile cel Mare din Iaşi», funcţionează prima clasă de religie ortodoxă de rit vechi care are în componenţă 15 elevi din rândul etniei ruşilor lipoveni, care se vor pregăti în domeniul teologiei pentru a servi Biserica Ortodoxă de Rit Vechi, cât mai ales pentru a preda religia ortodoxă de rit vechi în învățământul laic. La 24 octombrie 2002, Sfântul Sobor al Bisericii Ortodoxe de Rit Vechi a aprobat Planul de învăţământ, precum şi Programa şcolară pentru clasa seminarială din cadrul Seminarului Teologic Ortodox «Sf. Vasile cel Mare» din Iaşi. Înfiiințarea clasei de religie ortodoxă de rit vechi a fost aprobată de Preafericitul părinte Teoctist, patriarh al Bisericii Ortodoxe Române, de Ministerul Culturii şi Cultelor, precum şi de Ministerul Educaţiei şi Cercetării, la data de 18 decembrie 2002"19.

Evenimentul avea să fie promovat atât de către mijloacele media ale Bisericii Ortodoxe Române ${ }^{20}$, cât și de presa lipoveană, aceasta din urmă punând la dispoziție tinerilor doritori criteriile privind admiterea în această clasă liceală ${ }^{21}$. Din păcate, această clasă nu a funcționat decât

${ }^{17}$ Nicu D. OCtavian, „Întâlnirea Prea Fericitului Părinte Patriarh Teoctist cu delegaţia cultului creștin de rit vechi din România (4 aprilie 2002)", în Biserica Ortodoxă Română, 1-6/2002, p. 167.

${ }^{18}$ Este vorba de anul 2003. Secretariatul de Stat Pentru Culte, Statul şi cultele religioase, București, Edit. Litera, 2018, p. 146.

19 *** „Minoritatea ruso-lipoveană - 2003”, disponibil la http://www.ispmn.gov.ro/ node/minoritatea-ruso-lipovean-2003 (accesat la data de 07.07.2019).

20 *** „Prima clasă de Teologie pentru Biserica Ortodoxă de Rit Vechi la Iași”, disponibil la https://basilica.ro/prima-clasa-de-teologie-pentru-biserica-ortodoxa-de-rit-vechila-iasi/ (accesat la data de 07.07.2019).

21 RedACȚiA, „Seminarul teologic liceal - Biserica Ortodoxă de Rit Vechi (profil teologic)", în Zorile, 4/2003, p. 7. 
câțiva ani, urmând să fie închisă din lipsă de elevi. Cercetătorul științific lipovean Petru Ivanof a fost unul dintre susținătorii organizării acestei clase teologice de rit vechi și chiar a salutat implicarea Bisericii Ortodoxe Române în acest proiect, fără de care, spune el, nu ar fi fost dus la bun sfârșit. Tot el, însă, ne spune că acest proiect nu a fost agreat de către o parte dintre clericii și credincioșii de rit vechi mai conservatori. Mai mult decât atât, condamnă și lipsa de implicare a Comunității Rușilor Lipoveni din România (CRLR) ${ }^{22}$.

$\mathrm{Cu}$ toate acestea, trebuie să reținem de aici deschiderea spre dialog și ajutor reciproc a celor două culte, un aspect care nu face decât să susţină o bună relaționare clădită decenii de-a rândul.

\section{Ora de religie}

Anul 2014 este marcat de inițiative și de cerințe privind excluderea orei de religie din programa școlară în România. În acea perioadă, o mână de oameni formată din intelectuali și oameni politici au cerut Ministerului Educației Naționale scoaterea orei de religie din trunchiul comun de învățământ pentru că, spun ei, instigă la violență și la intoleranță față de alte culte, minorități sexuale sau liberi cugetători. În acest sens, la data de 28 februarie 2015, Consiliul Consultativ al Cultelor din România s-a întrunit la Reședința Patriarhală pentru a reafirma și saluta decizia Curții Constituționale a României ${ }^{23}$ de a menține religia în câmpul disciplinelor obligatorii.

La această întrunire a participat și o delegație din partea Bisericii Ortodoxe de Rit Vechi din România și a Comunității Rușilor Lipoveni din România, formată din Părintele Ioan Bordeanu (parohul bisericii ortodoxe de rit vechi „Înălțarea Domnului din București”) și Silviu Feodor (director executiv al CRLR) care au expus mesajul de susținere a predării religiei în școli, aparținând Înaltpreasfințitului Leontie, Arhiepiscop de Fântâna Albă și București şi Mitropolit al tuturor creștinilor ortodocși de rit vechi din întreaga lume, întrucât și „,pentru

22 Petru IVANOF, „Prima clasă la Seminarul teologic liceal de rit vechi din România”, în Zorile, 10(134)/2003, p. 10; IDEM, „Din nou despre Seminarul Liceal Ortodox de Rit Vechi”, în Zorile, 12(136)/2003, p. 6.

23 Decizie publicată în Monitorul Oficial, partea I, nr. 59 din 23 ianuarie 2015. 
credincioșii de rit vechi, etnicii ruși lipoveni, religia a reprezentat și reprezintă forma cea mai puternică de identitate și de existență’" ${ }^{\prime 2}$.

Şi acest lucru reprezintă o dovadă a deschiderii spre dialog a Bisericii Ortodoxe de Rit Vechi din România cu Biserica Ortodoxă Română.

\section{Concluzii}

- Studiul de față oferă o perspectivă cât mai actuală a dialogului și a relației dintre cele două culte. Am reușit să plecăm de la cel mai vechi și să ajungem la cel mai nou argument care susține acest lucru.

- Cercetarea noastră este importantă pentru apropierea dintre cele două Biserici, o apropiere care, sperăm noi, să treacă de pragul relației și a dialogului. Studiul se limitează doar la prezentarea pe scurt a evenimentelor istorice care argumentează acest subiect.

- Studiul nostru îmbogățește bibliografia privind cultul de rit vechi din țara noastră, tocmai pentru că despre acest subiect s-a scris extrem de puțin, mai ales din perspectiva teologiei ortodoxe românești.

- Considerăm că mai există și alte dovezi privind relația și dialogul dintre Biserica Ortodoxă Română și Biserica Ortodoxă de Rit Vechi din România care nu au fost expuse aici. Pe viitor, nădăjduim să elaborăm un alt studiu care să vină în completarea acestuia de față.

\section{Referințe bibliografice:}

1. ALEXE, Ștefan, „Relațiile Bisericii Ortodoxe Române cu celelalte culte religioase din țara noastră", în Ortodoxia, 2/1973, p. 193-209;

2. FlenChEA, Petru, Municipiul Roman şi comunitatea ruşilor-lipoveni, București, Edit. Papirus Media, 2009;

${ }^{24}$ REDACȚIA, „Importanța orei de religie pentru educația copiilor și a tinerilor”, în Zorile, 3(268)/2015, p. 10; *** „Consiliul Consultativ al Cultelor din România reafirmă importanța orei de religie pentru educația copiilor și tinerilor", disponibil la https://basilica.ro/consiliul-consultativ-al-cultelor-din-romania-reafirma-importanta -orei-de-religie-pentru-educatia-copiilor-si-tinerilor/ (accesat la data de 07.07.2019). 
3. HIMCINSCHI, Mihai, Misiune și dialog - ontologia misionară a Bisericii din perspectiva dialogului interreligios, Alba Iulia, Edit. Reîntregirea, 2003;

4. IONIȚĂ, Alexandru, Episcopul Melchisedec Ștefănescu al Romanului. Viața și activitatea (1822-1892). Teză de doctorat, Constanța, 1999;

5. IVANOF, Petru, „Prima clasă la Seminarul teologic liceal de rit vechi din România", în Zorile, 10(134)/2003, p. 10;

6. IDEM, „Din nou despre Seminarul Liceal Ortodox de Rit Vechi”, în Zorile, 12(136)/2003, p. 6;

7. MeleșCANU, Tiberiu, „Conferințe intercultice”, în Mitropolia Moldovei şi Sucevei, 8-9/1956, p. 503-507;

8. OCtaVian, Nicu D., „Întâlnirea Prea Fericitului Părinte Patriarh Teoctist cu delegația cultului creștin de rit vechi din România (4 aprilie 2002)", în Biserica Ortodoxă Română, 1-6/2002, p. 166-168;

9. PĂCURARIU, Mircea, Dicționarul teologilor români, ed. a II-a, București, Edit. Enciclopedică, 2002;

10. REDACȚIA, „Acțiuni pentru întărirea păcii. Conferințe interconfesionale”, în Mitropolia Moldovei şi Sucevei, 5/1956, p. 301-306;

11. REDACȚIA， „Comunicarea adresată conducătorilor şi comunităţilor Ortodoxe Ruse de rit vechi de către serviciul Patriarhiei din Moscova pentru relaţii bisericeşti externe", în Biserica Ortodoxă Română, 34/1972, p. 320;

12. REDACȚIA, „Importanța orei de religie pentru educația copiilor și a tinerilor", în Zorile, 3(268)/2015, p. 10;

13. REDACȚIA, „Manifestările clerului în lupta pentru pace împotriva experiențelor termonucleare", în Mitropolia Moldovei și Sucevei, 89/1957, p. 710-713;

14. REDACȚIA, „Moartea Arhiepiscopului Iosif, întâistătătorul Bisericii creştine de rit vechi din Uniunea Sovietică", în Biserica Ortodoxă Română, 3-4/1971, p. 279;

15. REDACȚIA, „Participarea Prea Fericitului Justinian la instalarea noului Mitropolit Ioasaf Timofei”, în Biserica Ortodoxă Română, 11-12/1968, p. 1269-1271;

16. REDACȚIA, „Ridicarea anatemei aruncate de sinoadele Bisericii Ortodoxe Ruse de la 1656 şi 1667 asupra «riturilor vechi» şi asupra credincioşilor de rit vechi”, în Biserica Ortodoxă Română, 9-10/1971, p. 1004-1005; 
17. REDACȚIA, „Seminarul teologic liceal - Biserica Ortodoxă de Rit Vechi (profil teologic)", în Zorile, 4/2003, p. 7;

18. SeCretariatul de Stat Pentru Culte, Statul şi cultele religioase, București, Editura Litera, 2018;

19. STĂCESCU, Constantin, „Conferința interconfesională pentru Pace de la Piatra Neamț”, în Mitropolia Moldovei și Sucevei, 11/1954, p. 90-92;

20. VASCENCO, Victor, „Melchisedec și lipovenii”, în Zorile, 5(176)/2007, p. 9-11;

21. IDEM, „Melchisedec şi lipovenii”, în Romanoslavica, vol. XLII, București, Editura Universității din București, 2007, p. 123-140;

22. *** „Consiliul Consultativ al Cultelor din România reafirmă importanța orei de religie pentru educaţia copiilor și tinerilor", disponibil la https://basilica.ro/consiliul-consultativ-al-cultelor-din-romania reafirma-importanta-orei-de-religie-pentru-educatia-copiilor-sitinerilor/ (accesat la data de 07.07.2019);

23.*** „Minoritatea ruso-lipoveană 2003”, disponibil la http:// www.ispmn.gov.ro/node/minoritatea-ruso-lipovean-2003 (accesat la data de 07.07.2019);

24. *** „Prima clasă de Teologie pentru Biserica Ortodoxă de Rit Vechi la Iași”, disponibil la https://basilica.ro/prima-clasa-de-teologie-pentrubiserica-ortodoxa-de-rit-vechi-la-iasi/ (accesat la data de 07.07.2019). 